\title{
Ruminating on Justin S. Ukpong's inculturation hermeneutics and its implications for the study of African Biblical Hermeneutics today
}

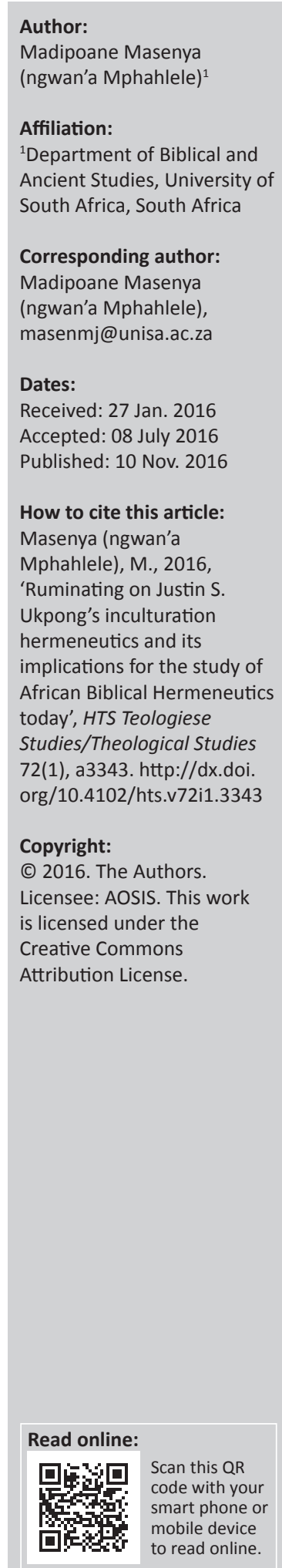

In African biblical scholarship, the concept of inculturation hermeneutics has come to be almost, if not always, linked to the late Professor Justin S. Ukpong, the Nigerian New Testament scholar. In inculturation hermeneutics, argued Ukpong, the past of the biblical text is not supposed to be studied as an end in itself, but as a means to an end. Ukpong (2002) could thus argue: 'Thus in inculturation hermeneutics, the past collapses into the present, and exegesis fuses with hermeneutics' (p. 18). What does Ukpong's concept of inculturation hermeneutics actually entail? Which implications does his notion of the fusion of exegesis and hermeneutics have for the theory and praxis of African Biblical Hermeneutics particularly on the African continent today? The preceding questions will be engaged with in this article.

Inculturation hermeneutics is a contextual hermeneutic methodology that seeks to make any community of ordinary people and their social-cultural context the subject of interpretation of the Bible through the use of the conceptual frame of reference of the people and the involvement of the ordinary people in the interpretation process. (Ukpong 2002:12; italics author's emphasis)

\section{Charting the conceptual frame of reference ${ }^{1}$}

One cannot do justice to Ukpong's concept of inculturation hermeneutics without foregrounding African social-cultural ${ }^{2}$ contexts in one's hermeneutical endeavours. Ukpong (2001a) reasoned: '... the African context forms the subject of interpretation of the Bible. The grid through which the Bible is read is developed from within Africa herself ...' (p. 24; see also Okure 2000:202). ${ }^{3}$ As an introduction to this article, I give a brief overview of the social-cultural context in which the character of Vashti in the Hebrew Bible could be approached through the lens of Ukpong's inculturation hermeneutics.

According to the Northern Sotho proverb, lefotwana ge e se la gago, o hloba le gaela, that is, if a baby bird is not yours, you remove its feathers even if it cries bitterly! Patriarchy, as well as its beneficiaries and advocates, is familiar with the ruthlessness embedded in the preceding proverb, the ruthlessness of removing with impunity, feathers of crying birds. The preceding proverb comes to mind when the metaphor of 'woman-as-exile at home' is applied to women in present day (South) African contexts. In her 2007 article entitled, 'Invisible Exiles? An African-South African Woman's Reconfiguration of "Exile" in Jeremiah 21:1-10', Masenya (ngwan'a Mphahlele) (2007) has argued:

Despite the significantly liberal South African constitution, female gender still very much determines the kind of position which a woman is expected to occupy in a contemporary South African patriarchal context .... Whether a woman is in the private sphere of the home, in the public sphere of work, church and the broader society, she remains in exile despite the fact that thirteen years ago she officially acquired citizenship in the country of her birth. (p. 759)

Looking at the present South African scenario, the words from the preceding quotation, written down 13 years post-independence, still hold water even today, 22 years into a post-apartheid state.

1.Elsewhere Ukpong reasons: 'A distinguishing feature of inculturation hermeneutics is its emphasis on using an African conceptual frame of reference in interpreting the Bible in Africa rather than using another conceptual frame for interpretation and applying the result in the African context' (2002a:23), "Inculturation Hermeneutics: An African Approach to Biblical Interpretation" in The Bible in a World Context: An Experiment in Contextual Hermeneutics, Dietrich Walter and Luz, Ulrich (eds), pp.17-32, Grand Rapids, Michigan/ Cambridge, UK: William B. Eerdmans, 2002.

2.For Ukpong, 'culture' is the totality of life of a human community. It entails the community's way of viewing reality as well as various activities such as the political, economic, social, leisure activities, the arts, textual productions among others (2002b:12) Such a holistic view of culture enables Ukpong to acknowledge the contribution of the ordinary and common place in knowledge production. Also within the ambit of inculturation hermeneutics, a variety of justice issues such as gender, race, social, economic, political and religious oppression and issues of indigenous cultural identity, customs and practices, are raised.

3.In a more or less similar vein, Okure (2000) is of the view that experiences of present day Bible readers, of necessity need to serve as point of departure in our Bible reading practices: 'Our contemporary life experiences are not only a valid standpoint for understanding the biblical text. They are the only standpoint we have. Experience is the primary context for doing theology and reading the Bible. Experience here is not feeling, but total emersion in life, being seasoned by life' (p. 202). 
The present burning issue about political leadership in South Africa can serve as a case in point. The observation that in the 104 years of the existence of the present ruling party in South Africa, that is, the African National Congress, the party has been led solely by men, is revealing. Also, 22 years into a democracy, in the so-called non-sexist, non-racist South Africa, men have been leading the country as presidents. Even the present call for female presidential leadership in this country is fraught with its own set of challenges.

The observation that the South African economy still remains basically in the hands of the historical winners while poverty continues to carry a black feminine face reveals some of the factors which continue to estrange African-South African women on own territory. The present 'Fees must fall' campaign, which was initiated by South African students in Higher Education, also points to the reality that our socialcultural context continues to be haunted by the legacies of the past racial inequalities, legacies which also entailed socioeconomic inequities based on one's skin pigmentation. The South African students are now asking if Higher Education should be the preserve of the rich to the exclusion of deserving poor (mostly black) students.

Economic empowerment does not only drive away hunger from households, it can also enable the poor to have a voice. Poverty has the capacity to sap not only our physical energies, but also our spiritual and mental capacities. A hungry person will struggle to think constructively, let alone critically. That gender-based violence has in fact escalated postindependence, also points in the direction of an alienating African context for women and girl children in the present day South Africa. The sacred texts of Christianity, to which many a Christian African woman continue to cling, and their use in and outside of the churches, do not seem to be helpful either. Women become estranged from their female selves because of the androcentric nature of some of the texts and the androcentric way in which the texts are mostly interpreted. At times, such interpretations estrange these strict adherents of religion from the deity in whose name such womenunfriendly interpretations are usually made. It is as if most men, not only the politically powerful, have a hold on many, a female just because they are female (cf, women in the Persian Empire as will be revealed by Vashti's narrative here below).

Also, the patriarchy embedded within African cultures continues to raise its ugly head even in the midst of Western modes of education, urbanisation, industrialisation and globalisation among others. In fact irrespective of how educated an African woman can be, entrenched patriarchal world views continue to make life difficult for her. A recent case in point can be cited. A woman who had agreed with her husband before his death that he would be buried in Johannesburg, the place where the deceased had stayed with his nuclear family for 18 years, was 'forced' to bury him (against the wishes of the deceased and her will) in Polokwane (400 km away!), the native town/village of the deceased. The deceased's parents and some of the extended family members (cf the communal African mentality?) were actively involved in the whole saga. According to the parents of the deceased, Johannesburg, irrespective of the fact that it was a place where their son had settled with his nuclear family for many years, could never be designated as home, ke nageng, it is a foreign space. It can thus not be a safe burial site for their son. Could it be that in this context where the whole is religious, ${ }^{4}$ such a (remote) space, would presumably not be recognised by the ancestors? An irony indeed! In the preceding case, patriarchy and the hierarchical African mentality thus gained the upper hand as in my view, the same incident would not have happened if the deceased was female, or if the widow was more elderly.

African women's experiences in what is naturally supposed to be their own territory at least on account of their Africanness can thus not resonate with the truth underlying the following Northern Sotho proverb, tšhipa e taga mohlabeng wa ga boyona. The tenor of the preceding proverb reveals that one naturally excels in their own natural home, that is, in the space to which they naturally belong.

In the light of the preceding brief overview of the present day South African context, one may ask: Are African women in South Africa any different from a bird-ling whose feathers are removed with impunity by those whom patriarchy does privilege? Informed by Ukpong's inculturation hermeneutics, how could one approach the character of Vashti in the Hebrew Bible?

\section{Enculturating the Vashti character in (South) Africa}

The basic hermeneutic theory at work is that the meaning of a text is a function of the interaction between the text in its context and the reader in their context. (Ukpong 2001:24)

The task of interpretation for Ukpong basically entails bringing the text within its historical-social context to bear on the (African) contexts of the present day ordinary Bible readers. For Ukpong (2001), exegesis and hermeneutics are thus not separate entities. They merge into one entity, thus enabling the past to collapse into the present because, there is '... one process of a reader who is critically aware of their context interacting with the text analysed in its context' (p. 25). ${ }^{5}$

The book of Esther is one of the two Hebrew Bible books that carry the name of a woman. Particularly with the dawn of contextual and/or liberationist approaches, the book of Esther has been read in a non-conventional way by various scholars to unpack androcentric ideologies (Maleke Kondemo 2015; Nadar 2002, 2003), classism (Masenya (ngwan'a

4.Inculturation hermeneutics adopts a holistic approach to culture [Bible is thus read within the religious and economic, social and political contexts of Africa (Ukpong 1995a, 2001a:24)]

5.Elsewhere, Ukpong reasons: 'The readings are mediated through a particular conceptual frame of reference derived from the world-view and the social-cultural context of a particular cultural community. This informs and shapes the exegetical context of a particular cultural community. This informs and shapes the exegetical
methodology and the reading practice and acts as a grid for making meaning of the methodology and
text' (2002b:21). 
Mphahlele) 2005; Mosala 1992), colonialism (Angela 2004), ethnocentricism and heterosexism (Bailey 2009) within the text. Especially to those who live as minorities in a foreign context, such as women in patriarchal contexts; this book, which depicts the life of the minority Jews in exile under the Persian rule, may be found appealing. It is within the preceding context where the minority Jews were overwhelmed, if not assimilated by the Persian Empire, and could get their cue from the heroine of the book, that is, Queen Esther. Despite her marginal status as an orphan, a Jew and a woman, she could still serve as a model to fellow Jews that human agency is possible amidst difficult circumstances. Does it then occasion any surprise that an even more marginalised character in the book of Esther, such as Vashti, could appeal to many a gender-sensitive woman scholar on account of her courage and boldness?

In this book, whose opening chapter (cf Esther 1) bluntly reveals the patriarchal context of the book's production; a reader is confronted with the harsh reality of a character who though upper class in terms of her royal status could not survive as she chose to challenge the voice (read: command) of the main patriarch of the empire, King Ahasuerus. In this article, I will use Vashti, the marginalised character of Esther, in an attempt to inculturate her to the context of African women in South Africa.

Arguments against the historicity not only of the Vashti character but also about the book of Esther as a whole weigh heavier than those in support of its historicity (Maleke Kondemo 2015:113-116). ${ }^{6}$ In many an African context though contexts that have prompted Ukpong to regard the Bible as 'a sacred classic $^{7}$ (cf. Ukpong 2002b:19), such arguments basically do not feature. As the texts are regarded as the Word of God, what would be important, argued Ukpong (2001b), would be to look for the message delivered by a specific text: 'If the people take the Bible as God's word and are interested in the message rather than the history or literary analysis of the biblical text, it was important to find out what they thought was the central message of the Bible' (p. 589). Informed by such contexts, and my commitment as a justiceseeking bosadi scholar, I read the Vashti character to see which insights she might bring, particularly towards the transformation of our contexts, ${ }^{8}$ if approached from the perspective of inculturation hermeneutics. In Ukpong's (2002b) view, the end goal of the interpretive process is:

\footnotetext{
6.There are a number of incidents in Esther which though cannot be shown to be unhistorical are contrary to Persian law and custom, for example the choice of unistorical are contrary to Persian law and custom, for example, the choice of a new queen from a gathering of virgins from all over the empire (cf. Esther 2 ) and the choice of Esther without inquiring of her race. There is existing evidence that Persi was not divided into 127 states or provinces. Also the fact that the names of the four main characters in the book of Esther, that is, Vashti, Esther, Haman and Mordecai are not known. For more details on this issue (see Berlin 2000).

7.For Ukpong (2001a), the Bible is thus a sacred classic, 'a book of devotion and norm of morality' (p. 25), but also an ancient literary work worth being given attention beyond its time.

8.Elsewhere, Masenya (ngwan'a Mphahlele) (2000) reasoned: Can I afford to take refuge in the study of the biblical past?

Whilst harsh economic realities and social problems look me in the eyes? Can I afford the luxury of sophisticated, controversial exegetical methods? While rape, malnutrition, women and child abuse are the order of the day in my environs? I dare not!

Make my context a hermeneutical key,

Let the Bible become the women's (people's) Bible! (Masenya [ngwan'a Mphahlele] 2000:21
}

the actualisation of the theological meaning of the text in today's context so as to forge integration between faith and life, and engender commitment to personal and societal transformation. (p. 24; cf. also Ukpong 2002a:18)

Like many an African-South African woman who are insiders to the South African (African) context, Vashti was an insider to the Persian imperial context. As noted earlier, the kind of treatment that African-South African women as females receive in what is supposed to be own territory fails to enable them to experience the truth embedded in the proverb, tšhipa e taga mohlabeng wa ga boyona Women thus struggle or even fail to shine on own territory. The kind of treatment that Vashti receives from men in Esther 1 persuades a reader to argue that Vashti also, mostly on account of her gender, could not shine effectively (read: excel) on own (natural) territory.

Especially before the dawn of feminist biblical hermeneutics in the seventies, and even today, dare one argue Vashti's character has been viewed in a negative light. In my view, Vashti's gender more than anything else served as a strong strike against her. Her 'foreign' gender in a patriarchal context sheds light on her foreign status in her own home front. Her resident alien status persisted despite her royal and socio-economic statuses within the Persian community.

\section{Elsewhere, Masenya (ngwan'a Mphahlele) (2005) argued:}

She is not treated as an independent character, but always delineated in relation to her husband ... As a matter of fact, Vashti never really appears as an independent character at all, except when she breaks the code of conduct by refusing to appear before the king, an act that culminates in her removal from the scene. Like an exile in a foreign country, Vashti cannot be allowed to possess her own will. She can only survive through being assimilated by patriarchy. Vashti is a stranger in what is supposed to be her own territory. (Masenya (ngwan'a Mphahlele) 2005:179-194)

It may thus be argued that though Vashti could have been made to feel at home by her ethnicity, queenly and socioeconomic statuses, her gender dictated that she would be exiled on own territory. As a queen, she could thus be deposed at once by a drunken king. As a wife, she could be divorced unilaterally and fast.

In my view, Vashti could have been allowed to shine according to the expectations and dictates of patriarchy, not naturally. Her refusal to appear before the king, thus asserting herself as an independent person (apart from her husband), cost her, her position as a queen (Maleke Kondemo 2015:130). One of the basic assumptions of the root paradigm of African culture which informs Ukpong's inculturation hermeneutic framework is the African holistic whole in which there is an interconnectedness between God, humanity and the cosmos, a sense of community whereby; a person is because they are (2002b:21). Viewed through such African communal eyes then, Vashti chose to her own peril, to neglect the spirit of communality in favour of an individualistic mentality. Her act of 'defiance' not only challenged Persian men's masculinities. 
Out of fear and concern of being further shamed by the powerless others, a decree had to be sent out '... declaring that every man should be master in his own house' (Est 1:22).

If Vashti was not a woman in a patriarchal context, a context in which beauty and obedience (read: female subservience to men) were true determinants of ideal womanhood, a context in which women as men's properties had to ensure that male honour and prestige were preserved at all costs, she would most probably not have met the fate which she had met. If she had acted according to the African communal and family mentalities, and obeyed the voice not only of the household patriarch, but also that of the patriarch of the Persian Empire, if Vashti, had only chosen not to go against the order established by both God and the ancestors, she would definitely not have experienced the disaster she had. Is it any wonder that in many an African ecclesiastical context, the Vashti character has been linked with disobedience and defiance, qualities which cannot be helpful in shaping the characters of Christian African women? On two different occasions, I listened to sermons based on Vashti and Esther presented by two pastors' wives. Both regarded Vashti as a disobedient wife who had no respect for her husband and for God. Emphasis was put mainly on the wifely loyalty towards a husband. The preachers did not seem to be concerned about the logic behind a drunken husband's summon of a wife to appear before drunken men. It is interesting that women who choose to be bed-fellows with patriarchy are also viewed as God-fearing women.

Our contexts have taught us that for the sake of survival, women have to allow themselves to be assimilated by patriarchy, operate according to its rules and get what they want. Those of us who choose to take our cue from Vashti must be willing to suffer the consequences of our daring to shine on own territory. An important question we ask is: How many poor ordinary African (South African) women can appropriate Vashti as a model?

So, unlike many 'ordinary' ${ }^{\prime}$ African women whose short narrative was outlined in the introductory section above, Vashti was not an ordinary Persian community member. As a queen, Vashti was an upper class woman. Is it any wonder that Vashti, like other women of class in the Hebrew Bible, was allowed not only a space in a relatively small scroll of Esther but also a 'voice'? Although the present day readers of the Hebrew Bible could only imply her voice through what the eunuchs communicated to King Ahasuerus, it is clear from the text that Vashti could think in a calculated and constructive way. As a rich woman, and a queen, Vashti could thus speak her mind and even dare to refuse to build a kraal around the king's voice. The Northern Sotho proverbial

9.Reasons Ukpong (2002b): "As a general category the term "ordinary people" refers to they live by the world-view provided by their traditional cultures, they are poor an marginalised, they suffer economic social and political disadvantage, and are found in both rural and urban areas' (p. 23). In his view, ordinary people are not trained Theologically and are on the whole, illiterate. 'However, continues Ukpong (2002b), They have a high sense of self-worth and would not be compromised because of the low social status. Scars of struggle for survival mark their lives' (Ukpong 2002b:23). saying, 'lentšu la kgoši le agwela lešaka', the voice of a kgoši has a kraal built around it' would not have mattered to Queen Vashti. How many poor African women could dare to take their cue from Vashti's courage, and dare to not support their husbands (read: kings), even if the latter might be out of line? Maleke Kondemo (2015) writing from a Mongo D.R. Congolese context rightly asks:

Can Vashti's courage which caused her to pay a high price be used in the affirmation of women's identities in today's modern society which is somehow similar to that of Vashti? ... A woman's body is seen as an object of sexual satisfaction. The society even today shows no respect for the rights of women and girls. Cases of girl trafficking are common, and the female body is used as a weapon (rape) in time of conflict. In societies where academic success or promotion in the workplace is not based only on the ability of a young girl or woman but on whether she grants the teacher or the boss access to her body, can Vashti be upheld as a role model for our children as we teach them to say 'No' to adults who try to molest or harm them? (p. 135-136)

She acknowledges that amidst poverty the latter is not easy to do but ventures to suggest that '.. it is important to find the courage to say "No"'.

\section{Inculturation hermeneutics and the biblical sciences in Africa today}

First, inculturation hermeneutics highlights the significant role of the Bible reader's context in our hermeneutical endeavours. The African social-cultural context is to be intentionally made the subject in our interpretive endeavours. In Ukpong's view, epistemological privilege is to be accorded to the ordinary readers. In 'inculturation hermeneutics' reasons Ukpong (2002a), '.. the primacy of the reading activity is located not among individual theologians working in isolation but among theologians working among communities of ordinary people - it is the ordinary people that are accorded the epistemological privilege' (p. 20). The elitist are thus encouraged to bring their critical tools to the equation even as they should be willing to be taught by the ordinary people (Ukpong 2001b). Ukpong is thus adamant that contextual hermeneutics remain critical when engaging the Bible in our African contexts. Perhaps, we all need to pause at this point and check if our biblical scholarship is committed more to our (elitist) peers than to people on the grassroots. In a secular state that South Africa is, in a context where upward mobility remains critical for all academics, including those in the disciplines of Biblical Studies, could the scholars' commitment to a biblical hermeneutic from below prove rewarding? In any case, do ordinary people whom Ukpong puts on a pedestal have access to what the elite write about? Could it be that Ukpong is suggesting that all African theologians and biblical scholars need to be engaged in Contextual Bible Studies (CBS) or any other related activities? Given the present day scenario in South Africa, where some preachers persuade ordinary people to eat rats, snakes, grass and drink petrol in the name of the display of God's power, should the epistemological privilege accorded the ordinary be foregrounded at all costs? 
What is also notable is that although Ukpong seems to acknowledge that the African culture is not innocent (Ukpong 2002b:18), in my view, he does not seem to take it on as one would have expected to be done by a scholar who claims to be committed to the transformation of our contexts. In that way, Ukpong does not seem to depart from the African theology of his predecessors and their whole-hearted embrace of African cultures. Gender-sensitive God-talk and biblical hermeneutics as they are employed mainly by African women theologians critique the African cultures for their lifedenying elements in African women's lives.

Second, the Bible remains a critical resource in Ukpong's inculturation hermeneutics. The text of the Bible has a message for the present day Bible readers. It has the capacity to effect not only personal transformation in the lives of African Christians but also societal transformation. Although elsewhere he argues that the word of God is communicated in human language and thus needs to be approached critically, ${ }^{10}$ Ukpong in my view seems to find the biblical text basically benevolent. The question that was raised about his relatively positive (read: neutral) view about the African culture may be raised even here. As the sacred texts of religious traditions ${ }^{11}$ in Africa have been used and continue to be used whether inadvertently or not, to marginalise other sectors, one wonders how helpful such an attitude towards the Bible might be in dismantling oppressive systems and structures.

Third, for Ukpong, exegesis and hermeneutics are not to be seen as separate entities. In Ukpong's opinion, exegesis is not to be done for its own sake. The past of the biblical text is studied with a view to seeing the kind of light it might throw to the present day ordinary people's contexts. A reader who is critically aware of a contemporary context enters the text whose context he/she is aware of, allowing the text to evoke appropriate responses, reactions and commitments in the readers' context. The social-cultural contexts of both the contexts that produced the texts as well as those of the present day African ordinary people are thus brought to bear on each other, with a view to the transformation of the lives of the present day ordinary people. ${ }^{12}$

Fourth, Ukpong's inculturation hermeneutics and the great store it sets by African cultures might be a call to (African) biblical scholars to get out of our silos (read: disciplines) and embrace MIT's (multi-, inter- and trans-disciplinarity) in our theory and praxis of biblical scholarship. The disciplines of sociology, African studies, anthropology and history among others might be used effectively by biblical scholars to enrich their own disciplines.

10.'It is God's Word in human language, which implies human culture with its ideology worldview, orientation, perspective, values and disvalues that are intertwined with the Word of God. This raises a need for a critical ethical reading in terms of its stance toward other peoples and cultures in the light of the basic human and biblical values of love and respect for others, justice, peace, unity and so on' (Ukpong 2002b:18).

11.Examples of popular sacred texts on the African continent includes the Koran and the Christian Bible. On account of the authority enshrined in the African folklore, it the Christian Bible. On account of the authority enshrined in the African folklore, it in Africa.

12.Ukpong does a brilliant work in this regard in his article on the parable of the shrewed manager in the Lukan text (1995b:189-210).

\section{Conclusion}

Concerned that Africans on the African continent had to answer questions that are posed by themselves, questions informed by what happens in the daily lives of ordinary people, convinced that the methods from the West cannot be sufficient in handling Biblical Studies that are taught on the continent, also persuaded by the belief that the Christian Bible has a significant contribution to make in the discipline of Biblical Studies, persuaded by the power of the gospel of Jesus Christ to transform lives, the late Professor Justin S. Ukpong set out to develop an African approach to engaging with the social-cultural contexts of both the ordinary people and those of the texts' productions, that is, inculturation hermeneutics.

Like the proverbial cattle that are praised only when they have finished the race, one would venture to applaud this great son of the African soil for all the contributions which he has made to African Biblical Hermeneutics. We are grateful for his generosity in leaving the great legacy for us all, and in particular, for the future generation of African biblical scholars. If the latter could only lend him their ears, they could be sure to make an invaluable contribution in the global village, thus contributing to the authenticity of the latter and its capacity to give room to voices that were hitherto, either unheard of, ignored and/or deliberately muted. To this great scholar, I dedicate this piece.

\section{Acknowledgements Competing interests}

The author declares that she has no financial or personal relationships which may have inappropriately influenced her in writing this article.

\section{References}

Angela, W.W.C., 2004, 'Esther', in D. Patte (ed.), Global Bible Commentary, pp. 135-140, Abingdon Press, Nashville, TN.

Bailey, R.C., 2009, 'That's why they didn't call the book Hadassah! The interse(ct)/(x) ionality of race/ethnicity, gender, and sexuality in the book of Esther', in R.C. Bailey, T.B. Liew \& F.F. Segovia (eds.), They were all together in one place? Toward minority Biblical Criticism, pp. 227-250, SBL, Atlanta, GA.

Berlin, A., 2000, 'Esther. The JPS Commentary', Jewish Publication Society, Philadelphia.

Maleke Kondemo, M., 2015, 'In search of affirming identities and role models: A gender-sensitive re-reading of the Vashti and Esther characters in the book of Esther within the Mongo of the Democratic Republic of the Congo', DTh thesis, University of South Africa, Pretoria.

Masenya (ngwan'a Mphahlele), M., 2000, Making the context of African-South African women a hermeneutical focus in theological education, A national initiative for the Contextualisation of Theological Education Publication 21, NICTE, the Contextualisation of
Johannesburg, South Africa.

Masenya (ngwan'a Mphahlele), M., 2005, 'Their hermeneutics was strange! Ours is a necessity! Rereading Vashti as an African-South African women', in C. Vander Stichele \& T. Penner (eds.), Her master's tools: Feminist and postcolonial engagements of historical-critical discourse, pp. 179-194, SBL, Atlanta, GA.

Masenya (ngwan'a Mphahlele), M., 2007, 'Invisible exiles? An African-South African woman's reconfiguration of "Exile" in Jeremiah 21:1-10", Old Testament Essays 20(3), 756-771.

Mosala, I.J., 1992, 'The implication of the text of Esther for African Women's struggle for liberation in South Africa', Semeia 59, 129-137.

Nadar, S., 2002, 'Gender, power, sexuality and suffering bodies in the book of Esther: Reading the characters of Esther and Vashti for the purpose of social transformation', Old Testament Essays 15(1), 113-130.

Nadar, S., 2003, 'Power, ideology and interpretations: Womanist and literary perspectives on the book of Esther as resources for gender-social transformation', $\mathrm{PhD}$ thesis, University of Natal, Pietermaritzburg. 
Okure, T., 2000, 'First was the life, not the book', in T. Okure (ed.), '... to cast fire upon the earth': Bible and mission collaborating in today's multicultural global context, pp. 194-227, Cluster, Pietermaritzburg.

Ukpong, J.S., 1995a, 'Reading the Bible with African eyes: Inculturation and hermeneutics', Journal of Theology for Southern Africa 91, 3-14.

Ukpong, J.S., 1995b, 'The parable of the shrwed manager (Luke 16: 1-13): An essay in inculturation Biblical hermeneutic', Semeia 73, 189-210.

Ukpong, J.S., 2001a, 'Developments in biblical interpretation in Africa: Historical and hermeneutical directions', in G.O. West \& M.W. Dube (eds.), Bible in Africa, transactions, trajectories and trends, pp. 11-28, Brill, Leiden.
Ukpong, J.S., 2001b, 'Popular readings of the Bible in Africa and implications for academic readings: Report on the field research carried out on oral interpretations project', in 0 . West \& M.W. Dube (eds.), Bible in Africa, transactions, trajectica and trends, pp. 582-591, Brill, Leiden.

Ukpong, J.S., 2002a, "Inculturation hermeneutics: An African approach to Biblical interpretation" in D. Walter \& L. Ulrich (eds.), The Bible in a world context: An experiment in contextual hermeneutics, pp. 17-32, William B. Eerdmans, Grand Rapids, MI.

Ukpong, J.S., 2002b, 'Reading the Bible in a global village: Issues and challenges from African readings', in J.S. Ukpong et al. (eds.), Reading the Bible in the global village: Cape Town, pp. 9-39, SBL, Atlanta, GA. 